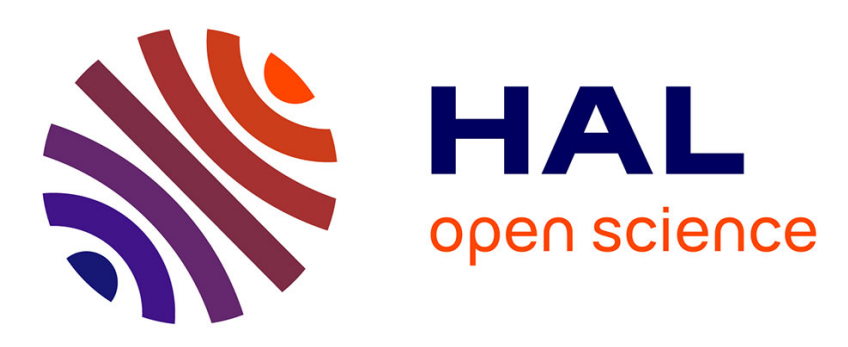

\title{
Blue highly fluorescent boron difluoride complexes based on phthalazine-pyridine.
}

\author{
Thi Minh Ha Vuong, Jennifer Weimmerskirch-Aubatin, Jean-François Lohier, \\ Nathalie Bar, Sophie Boudin, Christophe Labbe, Fabrice Gourbilleau, Hien T. \\ Nguyen, Tung Thanh Dang, Didier Villemin
}

\section{To cite this version:}

Thi Minh Ha Vuong, Jennifer Weimmerskirch-Aubatin, Jean-François Lohier, Nathalie Bar, Sophie Boudin, et al.. Blue highly fluorescent boron difluoride complexes based on phthalazine-pyridine.. New Journal of Chemistry, 2016, 40 (7), pp.6070-6076. 10.1039/C6NJ00726K . hal-01388831

\section{HAL Id: hal-01388831 https://hal.science/hal-01388831}

Submitted on 25 Jun 2018

HAL is a multi-disciplinary open access archive for the deposit and dissemination of scientific research documents, whether they are published or not. The documents may come from teaching and research institutions in France or abroad, or from public or private research centers.
L'archive ouverte pluridisciplinaire HAL, est destinée au dépôt et à la diffusion de documents scientifiques de niveau recherche, publiés ou non, émanant des établissements d'enseignement et de recherche français ou étrangers, des laboratoires publics ou privés. 


\title{
Blue highly fluorescent boron difluoride complexes based on phthalazine-pyridine
}

\author{
Thi Minh Ha Vuong, ${ }^{1}$ Jennifer Weimmerskirch-Aubatin, ${ }^{2}$ Jean-François Lohier, ${ }^{1}$ \\ Nathalie Bar, ${ }^{1}$ Sophie Boudin, ${ }^{3}$ Christophe Labbe, ${ }^{2}$ Fabrice Gourbilleau, ${ }^{2}$ \\ Hien Nguyen, ${ }^{4}$ Tung Thanh Dang ${ }^{4}$ and Didier Villemin ${ }^{\star 1}$
}

\begin{abstract}
Three new boron difluoride complexes based on phthalazine-pyridine, denoted (6), (7) and (8), have been synthesized and their photophysical and electrochemical properties have been studied. Solutions of these new $\mathrm{BF}_{2}$-complexes exhibit an intense blue fluorescence under UV light at low concentrations. Fluorescence quantum yields (QYS) have been determined by photoluminescence (PL) spectroscopy and decay times $(\tau)$ by semi-empirical methods. QYs of (6), (7) and (8) vary from $25 \%$ to $79 \%$. HOMO and LUMO energy levels have been estimated by cyclic voltammetry and PL spectroscopy. The HOMO and LUMO energy levels, at $\sim-5.3 \mathrm{eV}$ and $\sim-2.3 \mathrm{eV}$, respectively, make these new complexes interesting candidates as blue emitters in OLED applications.
\end{abstract}

\section{Introduction}

The design and synthesis of functionalised aza-BODIPY complexes have attracted huge interest in diverse research fields. ${ }^{1}$ In particular, aza-BODIPY has been thoroughly investigated to be applied in optoelectronic devices such as fluorescent sensors, ${ }^{2}$ fluorescent indicators, ${ }^{3}$ and fluorescent switches, ${ }^{4}$ laser dyes, ${ }^{5}$ organic photovoltaic cells ${ }^{6}$ and OLEDs. ${ }^{7}$ The families of boron complexes are based on $\mathrm{N}^{\wedge} \mathrm{O}, \mathrm{C}^{\wedge} \mathrm{O}$, and $\mathrm{N}^{\wedge} \mathrm{N}$ chelates rigidified by a boron fragment. $^{2}$ There are many types of boron complexes with various rings, the five- and six-membered rings are the most common ones. Among them, the six-membered ring type I boron complexes (Scheme 1) have been synthesized by the condensation of pyridine derivatives with subsequent chelation of the resulting Schiff base. ${ }^{8}$ They exhibit weak fluorescence quantum yields in solution due to their vibrational deactivation but are important ones in the solid state as a result of aggregation-induced emission. ${ }^{8 a, b, e}$ Most of the compounds of type II have been synthesized based on various palladium-catalysed cross-coupling reactions as a key step. ${ }^{9}$ Their boron complexes exhibit large Stokes shifts along with high quantum yields both in solution and in the solid state. ${ }^{9 a, b, e}$

\footnotetext{
${ }^{1}$ LCMT, ENSICAEN - CNRS - UNICAEN, 6 boulevard du Maréchal Juin, 14050 Caen, France. E-mail: villemin@ensicaen.fr

${ }^{2}$ CIMAP, ENSICAEN - CNRS - CEA - UNICAEN, 6 boulevard du Maréchal Juin, 14050 Caen, France

${ }^{3}$ CRISMAT, ENSICAEN - CNRS - UNICAEN, 6 boulevard du Maréchal Juin, 14050 Caen, France

${ }^{4}$ Hanoi University of Education, Faculty of Organic Chemistry, 136 Xuan Thuy Street, Cau Giay District, Hanoi, Vietnam
}<smiles>[R][Y]1=C([R])N=C([R])N([R])C1[R]</smiles><smiles>[R]C1=NB(F)N2CCCCC2=C[Y]1([Y9])F</smiles><smiles></smiles>

$\mathrm{X}=\mathrm{C}-\mathrm{R}$ or $\mathrm{N}$

Scheme 1: Various six-membered rings of $N, N$ chelation modes.

In the case of type III complexes, it is difficult to develop a synthetic step/procedure for their synthesis because of the different constructions in both sides of the six-membered ring. Interestingly, in this type $\mathrm{III},{ }^{10}$ Kobayashi et al. reported the synthesis of pyrrolopyrrole aza-boron difluoridepyrroles based on modified diketopyrrolopyrroles and azapyrrolopyrroles. ${ }^{10 b, c, g, i}$ Their important electronic delocalization over the $\pi$-conjugated backbone made these boron complexes highly fluorescent in the red and near infra-red regions. ${ }^{10 a-c, i}$ The azaboron diquinomethene complexes $^{10 h}$ have been reported as highly fluorescent blue and green emitters. Based on the above-mentioned studies, in this work, we describe the synthesis as well as the photophysical and electrochemical properties of three new pyridine-iminophthalazine chelates of boron(III) synthesized through a new simple procedure.

\section{Results and discussion}

\section{Synthesis}

The synthetic approaches for boron(III) complexes are depicted in Scheme 2. Two $\mathrm{N}^{\wedge} \mathrm{N}$ bi-dentate ligands (4) and (5) based on 2-aminopyridine and phthalazine were obtained after three 


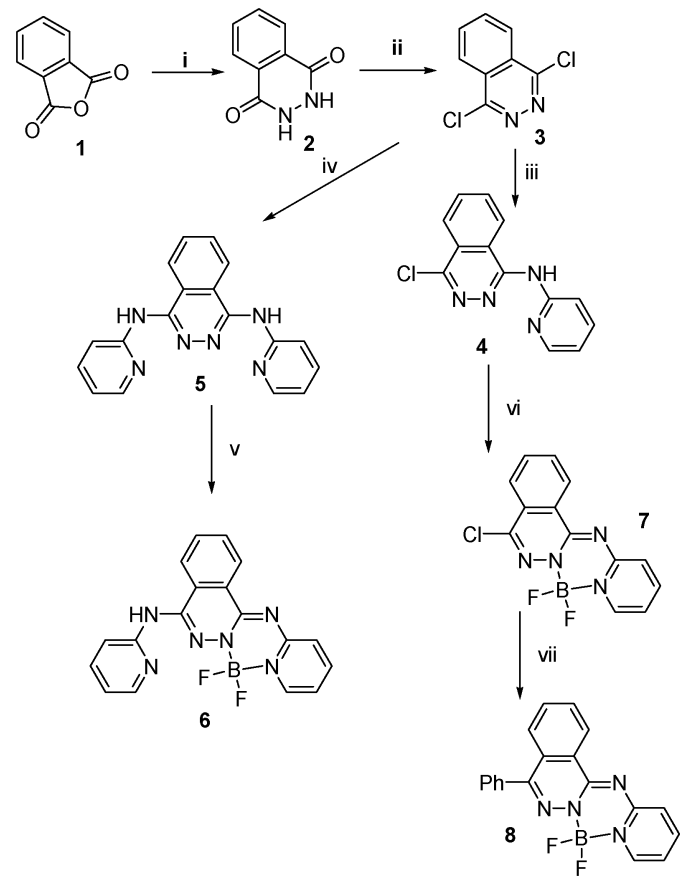

Scheme 2: Synthesis of boron difluoride complexes based on phthalazinepyridine: (i) $\mathrm{NH}_{2} \mathrm{NH}_{2} \cdot \mathrm{H}_{2} \mathrm{O}$ (1.1 eq.), acetic acid, $120^{\circ} \mathrm{C}, 4 \mathrm{~h}$, (yield $93 \%$ ); (ii) $\mathrm{POCl}_{3}$ (4.0 eq.), $110{ }^{\circ} \mathrm{C}, 1 \mathrm{~h}$ (yield 83\%); (iii) 2-aminopyridine (1.1 eq.), $\mathrm{NaH}$ (4.0 eq.), dioxane, $60{ }^{\circ} \mathrm{C}, 16 \mathrm{~h}$ (yield 47\%); (iv) 2-aminopyridine (2.1 eq.), $\mathrm{NaH}$ (4.8 eq.), dioxane, $60{ }^{\circ} \mathrm{C}, 16 \mathrm{~h}$ (yield 59\%); (v) and (vi) $\mathrm{Et}_{3} \mathrm{~N}(0.5 \mathrm{~mL}), \mathrm{BF}_{3} \mathrm{Et}_{2} \mathrm{O}(1.5 \mathrm{~mL})$, THF/toluene, reflux, overnight (yield 41\%); (vii) $\mathrm{C}_{6} \mathrm{H}_{5} \mathrm{~B}(\mathrm{OH})_{2}$ (1.1 eq.), $\mathrm{Pd}\left(\mathrm{PPh}_{3}\right)_{2} \mathrm{Cl}_{2}(5 \% \mathrm{mmol}), \mathrm{K}_{2} \mathrm{CO}_{3}\left(2.0\right.$ eq.), dioxane $/ \mathrm{H}_{2} \mathrm{O} 4 / 1, \mathrm{MW} 110{ }^{\circ} \mathrm{C}$, 60 min (yield 75\%).

classical steps. The first step is the synthesis of 2,3- $N, N$-dihydrophthalazine-1,4-dione (2) by condensation of phthalic anhydride and hydrazine in acetic acid. Continuously, compound (2) was reacted with phosphoryl chloride to give 1,4-dichlorophthalazine (3). Then, 1-chloro-4-(2'-pyridyl)aminophthalazine (4) and 1,4-di (2'pyridyl)aminophthalazine (5) were obtained by suitable equivalent addition of sodium hydride and 2-aminopyridine. By sequential treatment of (4) and (5) with boron trifluoride etherate in the presence of triethylamine in toluene, $\mathrm{BF}_{2}$-complexes (6) and (7) were synthesized with a yield of approximately $40 \%$. Substitution of the chloro group of complex (7) by a phenyl group of complex (8) was achieved via a Suzuki Palladium-catalysed cross coupling. ${ }^{11}$ All new compounds were structurally characterized by ${ }^{1} \mathrm{H},{ }^{11} \mathrm{~B}$, ${ }^{9} \mathrm{~F},{ }^{13} \mathrm{C}$ NMR and HRMS spectroscopies.

\section{Crystal structure}

The structure of complex (6) presented in Fig. 1 was unambiguously characterized by X-ray crystallography analysis. Crystal data are given in the Experimental section.

In the molecule, the opposite atoms $\mathrm{B} 1$ and $\mathrm{N} 5$ deviate from the mean N2 C8 N5 C14 N6 B1 ring plane (R.M.S. deviation of fitted atoms $=0.1092)$ by $0.1136(9)$ and $0.1731(9) \AA$, respectively, which leads to a boat-shaped deformation. The dihedral angle between the pyridine ring and the pyridazine ring is $14.546(69)^{\circ}$.

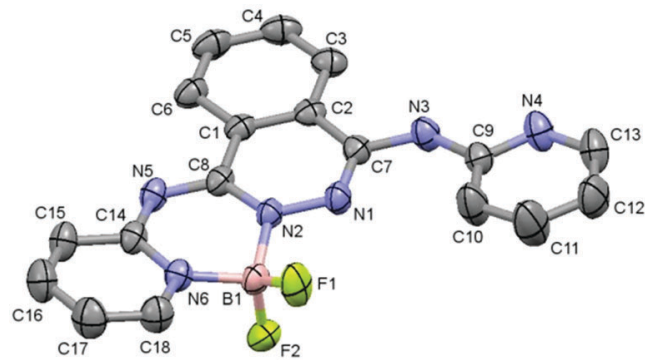

Fig. 1: Structure of complex (6). Selected bond lengths $(\AA)$, angles $\left(^{\circ}\right)$ and dihedral angles $\left({ }^{\circ}\right)$ : N6-B1 1.5568(18), N2-N1 1.3759(14), N2-B1 1.5387(18), N3-H1 0.860(18), B1-F1 1.3652(17), B1-F2 1.3913(18), F1-B1-F2 110.64(12), N1-N2-B1 113.22(10), N2-B1-N6 105.79(10).

The B-F and B-N bond lengths are inequivalent with distances of 1.3652(17) and 1.3913(18) $\AA$ and 1.5387(18) and 1.5568(18) respectively.

The crystal structure of complex (6) showed several intermolecular interactions. Four hydrogen bonds between complexes and water molecules (Fig. 2 bottom) are present and summarised in Table 1.

An additional strong $\mathrm{CH} \cdots$ halogen interaction $[\mathrm{C} 18-\mathrm{H} 18 \cdots \mathrm{F} 2=$ $2.28 \AA]$ is also present; the distance between the atoms involved is far less than the sum of the van der Waals radii of these atoms,
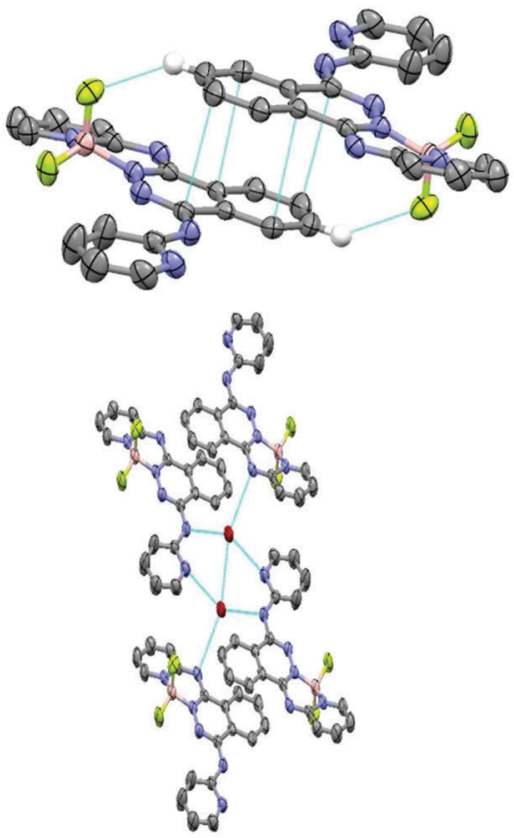

Fig. 2: Intermolecular interactions in crystals of (6).

Table 1: Hydrogen-bond geometry $\left(\AA,^{\circ}\right)$

\begin{tabular}{lllll}
\hline $\mathrm{D}-\mathrm{H} \cdots \mathrm{A}$ & $\mathrm{D}-\mathrm{H}$ & $\mathrm{H} \cdots \mathrm{A}$ & $\mathrm{D} \cdots \mathrm{A}$ & $\mathrm{D}-\mathrm{H} \cdots \mathrm{A}$ \\
\hline $\mathrm{O} 1-\mathrm{H} 7 \cdots \mathrm{N} 5$ & $0.90(2)$ & $2.04(2)$ & $2.934(2)$ & $175.5(19)$ \\
$\mathrm{O} 1-\mathrm{H} 8 \cdots \mathrm{N} 4^{\mathrm{i}}$ & $0.84(2)$ & $2.09(2)$ & $2.899(2)$ & $161(2)$ \\
$\mathrm{O} 1-\mathrm{H} 8 \cdots \mathrm{O} 1^{\mathrm{ii}}$ & $0.84(2)$ & $2.55(2)$ & $2.940(2)$ & $109.7(18)$ \\
$\mathrm{N} 3-\mathrm{H} 1 \cdots{ }^{\mathrm{iii}}$ & $0.86(2)$ & $2.21(2)$ & $3.043(2)$ & $161.4(15)$
\end{tabular}

Symmetry codes: (i) $1+x, y, z$; (ii) $2-x, 1-y,-z$; (iii) $1-x, 1-y,-z$. 
i.e. $2.67 \AA$. The cohesion of organic molecules within the crystal is finally reinforced by $\pi-\pi$ intermolecular interactions between phtalazine rings, the distance from plane to plane being $3.435 \AA$ (Fig. 2 up).

\section{Photophysical properties}

Quantum yield determination. The relative quantum yields (QYs) $\Phi$ of the boron(III) complexes (6), (7), and (8) were determined using the following formula: ${ }^{12}$

$$
\frac{\Phi_{\mathrm{x}}}{\Phi_{\mathrm{R}}}=\frac{A_{\mathrm{R}}}{A_{\mathrm{x}}} \times \frac{E_{\mathrm{x}}}{E_{\mathrm{R}}} \times \frac{n_{\mathrm{x}}^{2}}{n_{\mathrm{R}}^{2}}
$$

where subscripts $\mathrm{x}$ and $\mathrm{R}$ refer to the sample and the reference, respectively, $A$ is the absorbance at the excitation wavelength, $E$ is the integrated photoluminescence (PL) intensity and $n$ is the refractive index of the solvent at the excitation wavelength. To determine the QY, two conditions must be satisfied: (i) the reference and the sample must absorb and emit light in the same wavelength range ${ }^{13}$ (ii) the excitation wavelength must be identical for the reference and the sample. To fulfil these requirements a reference solution of anthracene in absolute ethanol was chosen and complexes (6), (7) and (8) were dissolved in chloroform. The QY reported by Dawson et al. ${ }^{14}$ for anthracene in ethanol was considered as reference. The absorbance spectra of complexes (6), (7), and (8) and anthracene are displayed in Fig. 3.

The absorbance spectra are composed of main peaks at $373 \mathrm{~nm}, 385 \mathrm{~nm} 391 \mathrm{~nm}$ and $405 \mathrm{~nm}$ wavelengths for complex (6), at $355 \mathrm{~nm}, 372 \mathrm{~nm}$ and $392 \mathrm{~nm}$ for complex (7), and at $336 \mathrm{~nm}$, $350 \mathrm{~nm}, 373 \mathrm{~nm}$, and $393 \mathrm{~nm}$ for complex (8). For each spectrum, the maximum absorbance peak wavelength is indicated in Fig. 3. The optical gap energies deduced from the absorption edges are $2.98 \mathrm{eV}, 3.09 \mathrm{eV}$ and $3.07 \mathrm{eV}$ for the complexes (6), (7), and (8), respectively (Table 3 ). The substitution of the chloro-group of complex (7) by the pyridylamino- or the phenyl-group in complexes (6) and (8) increases the number of molecular orbitals

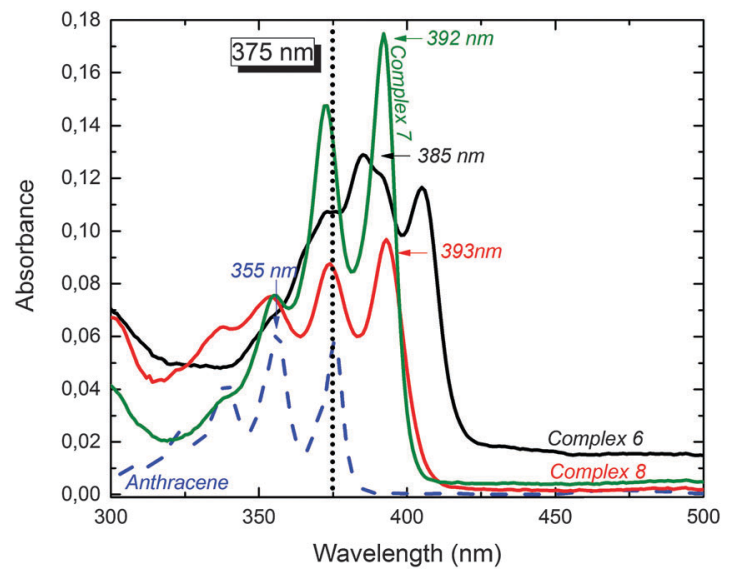

Fig. 3: Room temperature (RT) absorbance spectra of reference solution (anthracene) and solutions of complexes (6), (7), and (8). For each solution, the most intense peak is indicated. and consequently reduces the optical gap energy, as shown by the trend $\Delta E_{\text {opt }}(7)>\Delta E_{\text {opt }}(8)>>\Delta E_{\text {opt }}(6)$.

Fig. 4 presents the PL Excitation (PLE) and PL spectra of the reference (anthracene), complexes (6), (7) and (8) solutions. The shapes of the PLE spectra are almost identical to the shape of the absorbance spectra in Fig. 3. The maximum absorption wavelengths for anthracene and complexes (6), (7) and (8) are similar to the maximum excitation ones, i.e. at $355 \mathrm{~nm}, 385 \mathrm{~nm}$, $391 \mathrm{~nm}$, and $392 \mathrm{~nm}$ respectively. The emission bands of complexes (6), (7), and (8) have almost the same shape, with sharper peaks for the complex (7). The maximum PL peaks for the anthracene and complexes (6), (7) and (8) are recorded at $398 \mathrm{~nm}, 420 \mathrm{~nm}, 398 \mathrm{~nm}$ and $400 \mathrm{~nm}$ respectively. The Stokes shifts for complexes (6), (7), and (8) are $2165 \mathrm{~cm}^{-1}, 449 \mathrm{~cm}^{-1}$ and $510 \mathrm{~cm}^{-1}$, respectively.

QYs of complexes (6), (7) and (8) have been determined using formula (1) and the absorption and photoemission data of anthracene and complexes (6), (7) and (8). In order to optimize the excitation wavelength for all the solutions, a compromise excitation wavelength of $375 \mathrm{~nm}$ was chosen. This choice is carefully detailed in the ESI. $\dagger$ The estimated QY $(\Phi)$ values are $25 \%, 52 \%$ and $79 \%$ for complexes (6), (7) and (8) respectively (Table 2 ). We can notice that the substitution of a

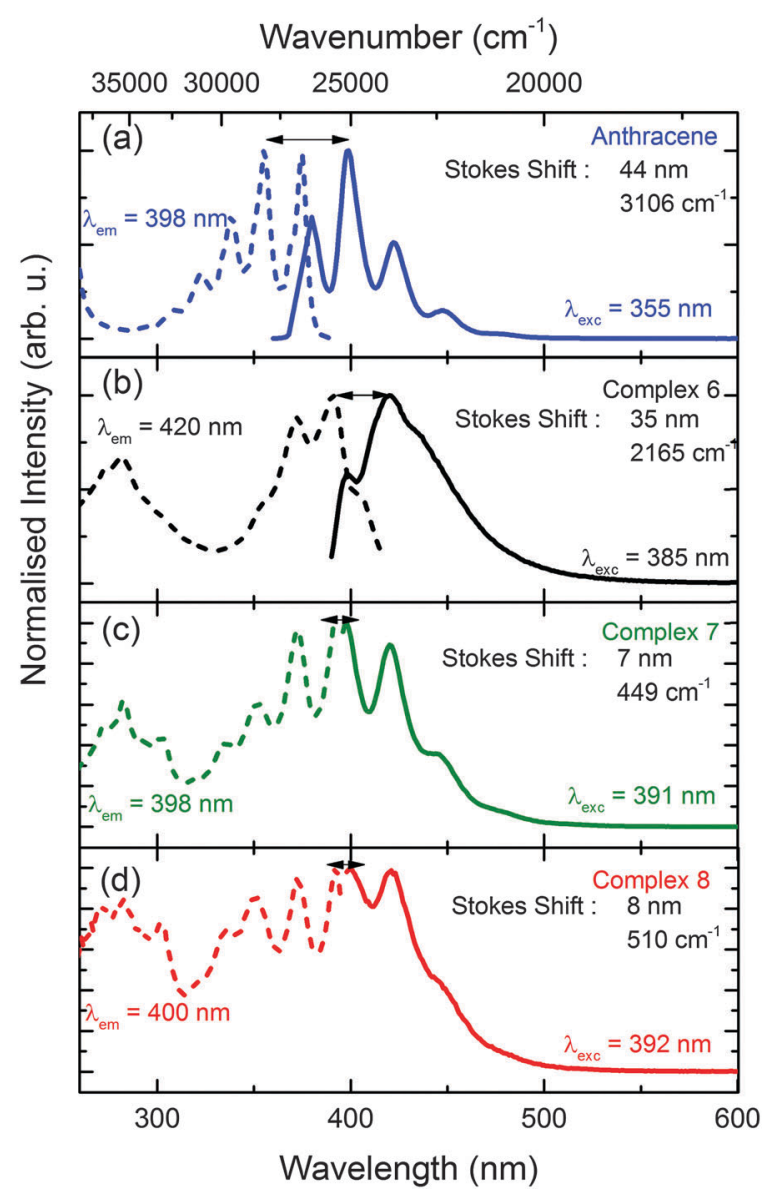

Fig. 4: RT PLE (dash line) and PL (continue line) spectra of (a) anthracene, (b) complex (6), (c) complex (7) and (d) complex (8). The values of the excitation or emission wavelengths and the Stokes shift are indicated. 
Table 2: Relative quantum yield (QY) and semi-empirical decay times $(\tau)$ calculated for anthracene and complexes (6), (7) a $\mathrm{n} \mathrm{d(8)}$

\begin{tabular}{lllc}
\hline & $\tau_{0}(\mathrm{~ns})$ & $\tau(\mathrm{ns})$ & $\Phi(\%)$ \\
\hline Anthracene & 6.0 & 1.7 & $28^{14}$ \\
Complex (6) & 3.6 & 0.9 & 25 \\
Complex (7) & 6.0 & 3.1 & 52 \\
Complex (8) & 4.0 & 3.1 & 79
\end{tabular}

phenyl group from complex (8) by a pyridylamino- or a chloro-group to complexes (6) and (7) decreases the fluorescence QY. Similar to the aza-boron-diquinomethene complexes reported by Wang et al., ${ }^{10 h}$ the substitution by a more electron-withdrawing or donating group decreases the QY. Compared to the QYs of other type (III) molecules, ${ }^{10 a-c, h, i}$ complexes (6) and (7) exhibit medium QYs and complex (8) is highly luminescent.

Semi-empirical determination of the decay time. Based on absorption and photoluminescence data, the luminescence decay times of complexes (6), (7) and (8) were estimated using the Strickler-Berg formula: ${ }^{15}$

$$
\frac{1}{\tau_{0}}=\frac{\Phi}{\tau}=2880 \times 10^{-9} n^{2} \frac{\int I(\nu) \mathrm{d} \nu}{\int \nu^{-3} I(\nu) \mathrm{d} \nu} \int \frac{A}{c \times d \times \nu} \mathrm{d} \nu
$$

where $\tau_{0}$ is the radiative decay time (s), in the absence of nonradiative recombination mechanisms, $\Phi$ is the quantum yield, $\tau$ is the measurable decay time, $n$ is the refractive index of the solvent at the excitation wavelength $\lambda_{\text {exc }}, I(\nu)$ is the intensity of the fluorescence spectrum, $A$ is the absorbance, $c$ is the concentration in mol cm$~^{-3}$ and $d$ is the length of the container in $\mathrm{cm}$. The frequency $\nu$ is in $\mathrm{cm}^{-1}$. The integration on the absorbance is not done on the whole absorption spectrum, but only from $300 \mathrm{~nm}$ to the

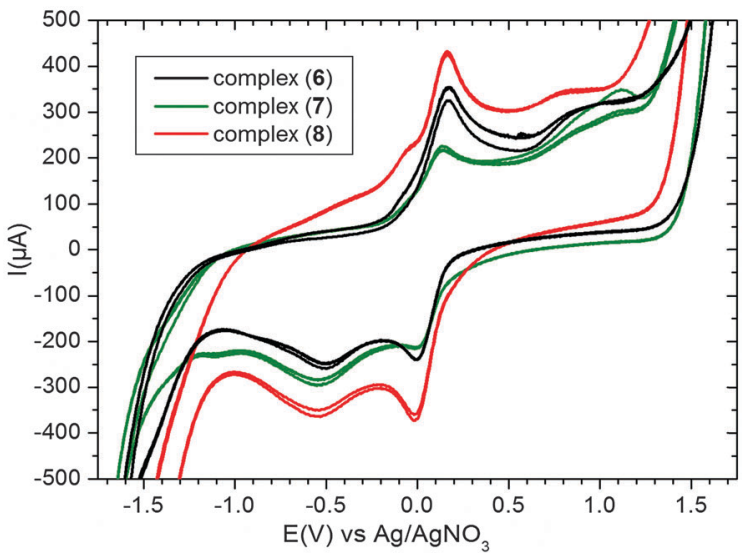

Fig. 5: Cyclic voltammograms of acetonitrile solutions of (6), (7) a $\mathrm{n} \mathrm{d} \mathrm{(8)}$ complexes $\left(2 \times 10^{-3} \mathrm{M}\right)$, ferrocene $\left(10^{-3} \mathrm{M}\right)$ and TBAP $(0.1 \mathrm{M})$. absorption edge. In order to test the validity of this formula, the semi-empirical decay time of anthracene was estimated first. The calculations led to the values $\tau_{0}=6.0 \mathrm{~ns}$ and $\tau=1.7 \mathrm{~ns}$, which are of the same order compared to the experimental value, $\tau_{\exp }=5 \mathrm{~ns}$, measured for anthracene in ethanol by Lampert et al. ${ }^{16}$ Similar calculations applied to the solutions of complexes (6), (7), and (8) led to $\tau_{(\mathbf{6})}=0.9 \mathrm{~ns}, \tau_{(7)}=3.1 \mathrm{~ns}$ and $\tau_{(8)}=3.1 \mathrm{~ns}$ respectively (Table 2). The decay times estimated for complexes (6), (7) and (8) are of the same order compared to the ones measured for similar molecules. ${ }^{10 h, i}$ These results have to be confirmed by appropriated decay time measurements, since the temporal detection limit of our equipment is higher than these values of decay times.

\section{Electrochemical properties}

HOMO and LUMO energy levels have been estimated from cyclic voltammetry. Cyclic voltammograms (CV) of (6), (7) and (8) complexes are shown in Fig. 5. The oxidation and reduction peaks of ferrocene/ferrocenium $\left(\mathrm{Fc} / \mathrm{Fc}^{+}\right)$used as reference are observed at $0.16 \mathrm{~V}$ and $0 \mathrm{~V}$ respectively. The (6), (7) and (8) complexes exhibit subtle oxidation peaks located at $E_{\text {peak max }}^{\text {oxy }}=$ $0.90 \mathrm{~V}, 1.12 \mathrm{~V}$ and $0.85 \mathrm{~V}$, respectively, and reduction peaks located at $E_{\text {peak max }}^{\text {red }}=-0.50 \mathrm{~V},-0.54 \mathrm{~V}$ and $-0.54 \mathrm{~V}$ respectively (Table 3). In order to confirm the attribution of the latter peaks to complexes (6), (7) and (8), CV of complex free solutions and of more concentrated complex solutions have been recorded (corresponding CV are reported in the ESI $\dagger$ ). The absence of oxidation and reduction peaks of complexes for the free complex solutions and the presence of more intense peaks for the more concentrated complex solutions confirm the previous attribution. The HOMO and LUMO energy levels of (6), (7) and (8) complexes have been deduced from the potentials of the oxidation peak onsets versus $\mathrm{Fc} / \mathrm{Fc}^{+} E_{\text {peak onset } v \text { s. Fc }}^{\text {oxy }}(\mathrm{V})$ and from the optical gap energies $\Delta E_{\text {opt }}$, estimated from the absorption edges (Table 3). The HOMO and LUMO energy levels are close for complexes (6), (7) and (8) with $E_{\mathrm{HOMO}} \sim-5.3 \mathrm{eV}$ and $E_{\text {LUMO }} \sim-2.3 \mathrm{eV}$. We can notice that the substitution of the phenyl group of complex (8) by a more electron donating or withdrawing group such as the pyridylamino- or chloro-group in complex (6) or (7) stabilizes the HOMO level as shown by the trend $E_{\text {Номо }}(8)>E_{\text {Номо }}(6)>E_{\text {Номо }}(7)$.

\section{Conclusions}

In this article, we described an efficient synthesis of new boron difluoride complexes based on phthalazine-pyridine which showed high intensive emission in solution. The photophysical properties of these novel emitters could be finely tunable through

Table 3: Electrochemical characteristics of complexes (6), (7) a n d ( 8)

\begin{tabular}{llllllll}
\hline & $E_{\text {peak max }}^{\text {red }}(\mathrm{V})$ & $E_{\text {peak max }}^{\text {oxy }}(\mathrm{V})$ & $E_{\text {peak onset }}^{\text {oxy }}(\mathrm{V})$ & $E_{\text {peak onset vs. Fc }}^{\text {oxy }}$ & $\Delta E_{\text {opt }}(\mathrm{eV})$ & $E_{\text {HOMO }}{ }^{a}(\mathrm{eV})$ & $E_{\text {LUMO }}{ }^{b}(\mathrm{eV})$ \\
\hline$(6)$ & -0.50 & 0.90 & 0.63 & 0.55 & 2.98 & -5.35 & -2.37 \\
$(7)$ & -0.54 & 1.12 & 0.66 & 0.58 & 3.09 & -5.38 & -2.29 \\
$(8)$ & -0.54 & 0.85 & 0.57 & 0.49 & 3.07 & -5.29 & -2.22
\end{tabular}

${ }^{a} E_{\mathrm{HOMO}}(\mathrm{eV})=-\mathrm{e}\left(E_{\text {peak onset } v \text { s. Fc }}^{\text {oxy }}(\mathrm{V})+4.8\right) .{ }^{b} E_{\mathrm{LUMO}}(\mathrm{eV})=E_{\mathrm{HOMO}}(\mathrm{eV})+\Delta E(\mathrm{eV})$. 
various substitutions at the 1-postion of the phthalazine core. The resulting complexes and their photophysical properties are currently being studied and will be attempted to be applied in OLED devices.

\section{Experimental}

\section{Synthesis and NMR characterisation}

All chemicals and solvents were purchased from chemical suppliers and were used as received, unless otherwise mentioned.

Purification of products was performed by column flash chromatography on Geduran ${ }^{\circledR}$ Si 60 silica gel $(40-63 \mu \mathrm{m})$ from Merck with analytically pure solvents. For analytical thin layer chromatography (TLC), silica gel-coated substrates "60 F254" from Merck were used and compounds were detected by illumination with a UV lamp $(\lambda=254$ or $365 \mathrm{~nm})$.

Microwave irradiation was done using a monowave 300 Anthon Paar cavity at $2450 \mathrm{MHz}$.

${ }^{1} \mathrm{H}$ and ${ }^{13} \mathrm{C}$ NMR experiments were recorded in the listed deuterated solvents (internal standard) on Avance 400 Bruker Spectrometers. Multiplicity of the NMR signal was denoted as br (broad), m (multiplet), s (singlet), d (doublet), and t (triplet). Mass analyses were carried out on an LCMS QTOF Micro WATERS machine.

2,3-Dihydrophthalazine-1,4-dione (2). A mixture of phthalic anhydride $(7.40 \mathrm{~g}, 50.0 \mathrm{mmol})$ and hydrazine hydrate $(2.80 \mathrm{~mL}$, $55.0 \mathrm{mmol}, 1.1$ eq.) was heated to $120{ }^{\circ} \mathrm{C}$ in acetic acid for $4 \mathrm{~h}$. Then, the reaction mixture was cooled to room temperature and filtered to give a white solid (7.52 g, 93\%). ${ }^{1} \mathrm{H}-\mathrm{NMR}$ (DMSO, $400 \mathrm{MHz}) \delta=11.53$ (br s, 2H), $8.06(\mathrm{~m}, 2 \mathrm{H}), 7.87$ (m, 2H).

1,4-Dichlorophthalazine (3). 2,3-Dihydrophthalazine-1,4dione (2) (7.52 g, $46.4 \mathrm{mmol})$ was heated to $110{ }^{\circ} \mathrm{C}$ in $18 \mathrm{~mL}$ (4 eq.) of phosphoryl chloride. After one hour, the reaction mixture was cooled to room temperature and added dropwise to crushed ice. The formed precipitate was filtered, washed with $\mathrm{H}_{2} \mathrm{O}$, and then dried in a vacuum to give a white solid $(7.64 \mathrm{~g}$, 83\%). ${ }^{1} \mathrm{H}-\mathrm{NMR}$ (DMSO, $\left.400 \mathrm{MHz}\right) \delta=8.34(\mathrm{~m}, 2 \mathrm{H}), 8.27(\mathrm{~m}, 2 \mathrm{H})$. ${ }^{13} \mathrm{C}-\mathrm{NMR}$ (DMSO, $\left.100 \mathrm{MHz}\right) \delta=155.2,136.2,127.1,126.1$.

1-Chloro-4(2'-pyridyl)aminophthalazine (4). Sodium hydride (60\% in mineral oil) $(1.60 \mathrm{~g}, 40.0 \mathrm{mmol})$ was carefully added into a mixture of 1,4-dichlorophthalazine (3) (1.99 g, $10 \mathrm{mmol})$ and 2-aminopyridine (1.034 g, $11.0 \mathrm{mmol}, 1.1 \mathrm{eq}$.) in $25 \mathrm{~mL}$ of freshly distilled dioxane. The resulting mixture was stirred at $60{ }^{\circ} \mathrm{C}$ for $16 \mathrm{~h}$. Then, it was quenched carefully with water and was acidified with aqueous hydrochloric acid $1 \mathrm{M}$. After that, the mixture was washed with $\mathrm{CHCl}_{3}(50 \mathrm{~mL} \times 3)$, and the organic phase was concentrated in a vacuum. The crude product was then purified by silica-gel column chromatography (eluted with cyclohexane/AcOEt: 3/1) to give the expected product as a white solid (1.21 g, 47\%). ${ }^{1} \mathrm{H}-\mathrm{NMR}$ (DMSO, $400 \mathrm{MHz}$ ) $\delta=10.02(\mathrm{~s}, 1 \mathrm{H}), 8.72(\mathrm{~d}, J=7.8 \mathrm{~Hz}, 1 \mathrm{H}), 8.36(\mathrm{~d}, J=4.4 \mathrm{~Hz}$, $1 \mathrm{H}), 8.24(\mathrm{~d}, J=7.8 \mathrm{~Hz}, 1 \mathrm{H}), 8.19(\mathrm{~d}, J=7.7 \mathrm{~Hz}, 2 \mathrm{H}), 8.08$ $(\mathrm{m}, 2 \mathrm{H}), 7.82(\mathrm{td}, J=7.7 \mathrm{~Hz}, 1.6,1 \mathrm{H}), 7.08(\mathrm{t}, J=6.0 \mathrm{~Hz}, 1 \mathrm{H})$. ${ }^{13} \mathrm{C}-\mathrm{NMR}$ (DMSO, $100 \mathrm{MHz}$ ) 153.7, 153.0, 148.4, 138.3, 134.2, 134.2, 133.8, 126.3, 125.2, 124.4, 121.4, 118.8, 115.0.
1,4-Di(2'-pyridyl)aminophthalazine (5). Sodium hydride (60\% in mineral oil) (1.60 g, $24.0 \mathrm{mmol}$ ) was carefully added into a mixture of 1,4-dichlorophthalazine (3) (0.98 g, $5 \mathrm{mmol})$ and 2-aminopyridine ( $0.98 \mathrm{~g}, 10.5 \mathrm{mmol}, 2.1 \mathrm{eq}$.) in $25 \mathrm{~mL}$ of distilled dioxane. The resulting mixture was stirred at $60{ }^{\circ} \mathrm{C}$ for $16 \mathrm{~h}$. Then, it was quenched carefully with water and was acidified with aqueous hydrochloric acid $1 \mathrm{M}$. After that, the solvent was removed and the residue was washed with $\mathrm{CHCl}_{3}$ to eliminate the non-reacted 2-aminopyridine. The crude product was then purified by silicagel column chromatography (eluted with AcOEt/MeOH: 10/1) to give the product as a white solid $(0.71 \mathrm{~g}, 59 \%) .{ }^{1} \mathrm{H}-\mathrm{NMR}\left(\mathrm{CD}_{3} \mathrm{OD}\right.$, $400 \mathrm{MHz}) \delta=8.98(\mathrm{dd}, J=6.1,3.3 \mathrm{~Hz}, 2 \mathrm{H}), 8.58(\mathrm{~d}, J=5.7 \mathrm{~Hz}, 2 \mathrm{H})$, 8.37 (dd, $J=6.1,3.3 \mathrm{~Hz}, 2 \mathrm{H}), 8.32(\mathrm{t}, J=7.2 \mathrm{~Hz}, 2 \mathrm{H}), 7.98$ $(\mathrm{d}, J=8.7 \mathrm{~Hz}, 2 \mathrm{H}), 7.52$ (dd, $J=7.2 \mathrm{~Hz}, 5.2 \mathrm{H}) .{ }^{13} \mathrm{C}-\mathrm{NMR}\left(\mathrm{CD}_{3} \mathrm{OD}\right.$, $100 \mathrm{MHz})$ 150.7, 148.8, 143.4, 140.5, 135.4, 124.4, 121.8, 119.6, 116.1, $[\mathrm{M}+\mathrm{H}]^{+}$calcd: 315.1358 , found: 315.1366 .

Complex (6).

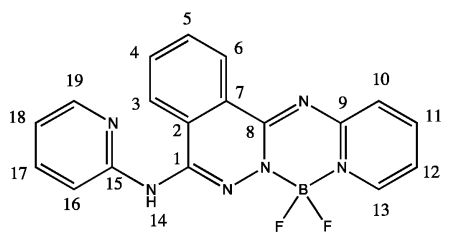

To 1,4-(2'-pyridyl)aminophthalazine $(5)(0.31 \mathrm{~g}, 1.0 \mathrm{mmol})$ in toluene/THF $0.5 \mathrm{~mL}$ of $\mathrm{Et}_{3} \mathrm{~N}$ was added, followed by the subsequent addition of $\mathrm{BF}_{3} \cdot \mathrm{OEt}_{2}(1.5 \mathrm{~mL})$ through a syringe. The reaction mixture was heated to reflux overnight. After cooling down to room temperature, the reaction mixture was extracted with AcOEt $(30 \mathrm{~mL} \times 3)$. The organic layers were combined, dried over anhydrous $\mathrm{Na}_{2} \mathrm{SO}_{4}$, filtered, and evaporated to dryness under vacuum. The crude product was purified by column chromatography on silica gel (cyclohexane/AcOEt: 1/1) to give the final product as a yellow powder $(0.15 \mathrm{~g}, 41 \%)$. ${ }^{1} \mathrm{H}-\mathrm{NMR}\left(\mathrm{CDCl}_{3}\right.$, $400 \mathrm{MHz}$ ) $\delta=8.89$ (d, $J=7.8 \mathrm{~Hz}, 1 \mathrm{H}, \mathrm{H} 6), 8.50$ (br s, 1H, H16), 8.21-8.12 (m, 2H, H13 and H19), 8.03 (br s, 1H, H3), 7.91 $(\mathrm{t}, J=7.8 \mathrm{~Hz}, 1 \mathrm{H}, \mathrm{H} 4), 7.83(\mathrm{t}, J=7.8 \mathrm{~Hz}, 1 \mathrm{H}, \mathrm{H} 5), 7.78$ (t, $J=8.3 \mathrm{~Hz}, 1 \mathrm{H}, \mathrm{H} 17), 7.72(\mathrm{t}, J=8.7 \mathrm{~Hz}, 1 \mathrm{H}, \mathrm{H} 11), 7.32$ (d, $J=8.7 \mathrm{~Hz}, 1 \mathrm{H}, \mathrm{H} 10), 6.98(\mathrm{t}, J=6.8 \mathrm{~Hz}, 1 \mathrm{H}, \mathrm{H} 12), 6.92$ (t, $J=6.4 \mathrm{~Hz}, 1 \mathrm{H}, \mathrm{H} 18) .{ }^{13} \mathrm{C}-\mathrm{NMR}\left(\mathrm{CDCl}_{3}, 100 \mathrm{MHz}\right) 153.7$ (C9), 152.6 (C15), 149.3 (C8), 147.4 (C19), 145.5 (C1), 140.3 (C11), 139.3 (C17), 137.4 (C13), 133.8 (C4), 132.4 (C5), 127.9 (C7), 127.8 (C6), 123.3 (C10), 122.6 (C2), 121.2 (C3), 117.9 (C18), 115.4 (C12), 113.7 (C16). ${ }^{19} \mathrm{~F}-\mathrm{NMR}\left(\mathrm{CDCl}_{3}, 376 \mathrm{MHz}\right)-137.61$ (br, 2F), ${ }^{11} \mathrm{~B}-\mathrm{NMR}$ $\left(\mathrm{CDCl}_{3}, 128 \mathrm{MHz}\right) 1.03(\mathrm{t}, J=25.27 \mathrm{~Hz}, 1 \mathrm{~B}),[\mathrm{M}+\mathrm{H}]^{+}$calcd: 363.1341, found: 363.1349 .

\section{Complex (7)}

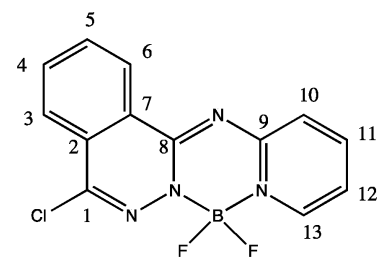

To 1-chloro-4(2'-pyridyl)aminophthalazine (4) $(0.51 \mathrm{~g}, 2.0 \mathrm{mmol})$ in $\mathrm{CHCl}_{3} 0.5 \mathrm{~mL}$ of $\mathrm{Et}_{3} \mathrm{~N}$ was added, followed by the subsequent 
addition of $\mathrm{BF}_{3} \mathrm{OEt}_{2}(1.5 \mathrm{~mL})$ through a syringe. The reaction mixture was heated to reflux overnight. After cooling down to room temperature, the reaction mixture was extracted with AcOEt $(30 \mathrm{~mL} \times 3)$. The organic layers were combined, dried over anhydrous $\mathrm{Na}_{2} \mathrm{SO}_{4}$, filtered, and evaporated to dryness under vacuum. The crude product was purified by column chromatography on silica gel (cyclohexane/AcOEt: $3 / 1$ ) to give the final product as a yellow powder $(0.27 \mathrm{~g}, 41 \%) .{ }^{1} \mathrm{H}-\mathrm{NMR}$ $\left(\mathrm{CDCl}_{3}, 400 \mathrm{MHz}\right) \delta=9.00(\mathrm{~d}, J=7.4 \mathrm{~Hz}, 1 \mathrm{H}, \mathrm{H} 6), 8.45($ br s, $1 \mathrm{H}$, H13), 8.26 (d, $J=7.4 \mathrm{~Hz}, 1 \mathrm{H}, \mathrm{H} 3), 8.09$ (t, $J=7.4 \mathrm{~Hz}, 1 \mathrm{H}, \mathrm{H} 4)$, $8.05(\mathrm{t}, J=7.4 \mathrm{~Hz}, 1 \mathrm{H}, \mathrm{H} 5), 8.02(\mathrm{t}, J=7.0 \mathrm{~Hz}, 1 \mathrm{H}, \mathrm{H} 11), 7.58$ (d, $J=8.6 \mathrm{~Hz}, \mathrm{H} 10), 7.26$ (t, $J=7.0 \mathrm{~Hz}, 1 \mathrm{H}, \mathrm{H} 12) .{ }^{13} \mathrm{C}-\mathrm{NMR}$ $\left(\mathrm{CDCl}_{3}, 100 \mathrm{MHz}\right) 153.5$ (C9), 150.8 (C8), 145.9 (C1), 141.4 (C11), 138.0 (C13), 134.3 (C4), 133.4 (C5), 127.9 (C7), 127.3 (C2), 127.2 (C6), 125.6 (C3), 123.6 (C10), 116.8 (C12). ${ }^{19} \mathrm{~F}-\mathrm{NMR}\left(\mathrm{CDCl}_{3}, 376\right.$ $\mathrm{MHz})-135.68(\mathrm{dd}, J=50.98 \mathrm{~Hz}, J=25.49 \mathrm{~Hz}, 2 \mathrm{~F}),{ }^{11} \mathrm{~B}-\mathrm{NMR}$ $\left(\mathrm{CDCl}_{3}, 128 \mathrm{MHz}\right) 0.89(\mathrm{t}, J=25.50 \mathrm{~Hz}, 1 \mathrm{~B}),[\mathrm{M}+\mathrm{Na}]^{+}$calcd: 327.0396, found: 327.0396 .

Complex (8).

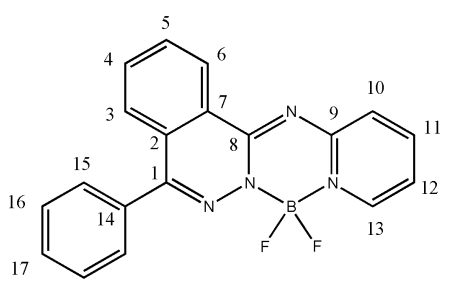

A mixture of complex (7) (0,32 g, $1.0 \mathrm{mmol})$, phenyl boronic acid (136 mg, $1.1 \mathrm{mmol}$ ), bistriphenylphosphine palladium(II) dichloride (70 mg, $0.05 \mathrm{mmol}$ ), and $\mathrm{K}_{2} \mathrm{CO}_{3}(276 \mathrm{mg}, 2 \mathrm{mmol})$ was dissolved in dioxane- $\mathrm{H}_{2} \mathrm{O}(4: 1,5.0 \mathrm{~mL})$. The resulting mixture was subjected to microwave irradiation for $60 \mathrm{~min}$ at $110{ }^{\circ} \mathrm{C}$. After cooling down to room temperature, the reaction mixture was extracted with $\mathrm{CHCl}_{3}(20 \mathrm{~mL} \times 3)$. The organic layers were combined, dried over anhydrous $\mathrm{Na}_{2} \mathrm{SO}_{4}$, filtered, and evaporated to dryness under vacuum. The crude product was purified by column chromatography on silica gel (cyclohexane/AcOEt: $4 / 1$ ) to give the final product as a yellow powder $(0.26 \mathrm{~g}, 75 \%) .{ }^{1} \mathrm{H}-\mathrm{NMR}\left(\mathrm{CDCl}_{3}, 400 \mathrm{MHz}\right) \delta=8.99(\mathrm{~d}, J=6.5 \mathrm{~Hz}$, $1 \mathrm{H}, \mathrm{H} 6), 8.32$ (d, $J=5.2 \mathrm{~Hz}, 1 \mathrm{H}, \mathrm{H} 13), 7.92-7.82(\mathrm{~m}, 4 \mathrm{H}, \mathrm{H} 3, \mathrm{H} 4$, H5 and H11), 7.75-7.69 (m, 1H, H15), 7.55-7.51 (m, 2H, H16 and H17), 7.50-7.45 (m, 1H, H10), 7.09 (t, $J=6.8 \mathrm{~Hz}, 1 \mathrm{H}, \mathrm{H} 12)$. ${ }^{13} \mathrm{C}-\mathrm{NMR}$ (CDCl, $\left.100 \mathrm{MHz}\right) 153.7$ (C9), 153.6 (C1), 150.8 (C8), 140.9 (C11), 137.8 (C13), 135.1 (C14), 133.5 (C4), 132.2 (C5), 130.0 (C15), 129.4 (C17), 128.6 (C16), 127.4 (C2), 127.3 (C7), 127.0 (C6), 126.7 (C3), 123.3 (C10), 116.1 (C12). ${ }^{19}$ F-NMR $\left(\mathrm{CDCl}_{3}, 376 \mathrm{MHz}\right)-135.82(\mathrm{dd}, J=50.38 \mathrm{~Hz}, J=25.19 \mathrm{~Hz}, 2 \mathrm{~F})$. ${ }^{11} \mathrm{~B}-\mathrm{NMR}\left(\mathrm{CDCl}_{3}, 128 \mathrm{MHz}\right) 1.28(\mathrm{t}, J=25.34 \mathrm{~Hz}, 1 \mathrm{~B}),[\mathrm{M}+\mathrm{H}]^{+}$ calcd: 369.1097, found: 369.1099.

\section{Single crystal $X$ ray diffraction}

Single crystals of (6) suitable for X-ray crystallographic analysis were obtained by slow evaporation of $\mathrm{CH}_{2} \mathrm{Cl}_{2}$ solution. X-ray diffraction data collection was performed at $150 \mathrm{~K}$ using graphite-monochromatized Mo $\mathrm{K}_{\alpha}$ radiation $(\lambda=0.71073 \AA$ ) on a Bruker-Nonius Kappa CCD area detector diffractometer.
Formula: $\mathrm{C}_{18} \mathrm{H}_{15} \mathrm{BF}_{2} \mathrm{~N}_{6} \mathrm{O}$; formula weight: 380.17 ; crystal system: monoclinic; space group: $P 2(1) / n$; cell parameters: $a=10.5846(4) \AA$, $b=7.6098(3) \AA, c=21.9235(10) \AA, \alpha=\gamma=90^{\circ}, \beta=100.651(2)^{\circ}$, $V=1735.44(12) \AA^{3} ; Z=4$; calculated density $=1.455 \mathrm{~g} \mathrm{~cm}^{-3}$; $\mu=0.110 \mathrm{~mm}^{-1} ; R_{\mathrm{int}}=0.0252 ; R\left[F^{2}>2 \sigma\left(F^{2}\right)\right]=0.0388$; $\mathrm{w} R\left(F^{2}\right)=0.1076$. Program(s) used to solve the structure: SHELXS97. Program(s) used to refine the structure: SHELXL-2014. Software used to prepare the material for publication: SHELXTL. CCDC 1030686.

\section{Absorbance and photoluminescence measurements}

The absorbance spectra were recorded at room temperature on a Perkin-Elmer UV-Visible Spectrophotometer with a resolution of $1 \mathrm{~nm}$. The PL and PLE spectra were measured at room temperature using a Horiba Jobin Yvon Fluorolog-3 spectrofluorimeter equipped with a $450 \mathrm{~W}$ xenon lamp, with a resolution of $1 \mathrm{~nm}$. Absorbance and photoluminescence spectra were recorded on $\mathrm{CHCl}_{3}$ solutions of complexes (6), (7) and (8) and on a reference solution of anthracene in absolute ethanol (4 $\mathrm{mg}$ dissolved in $250 \mathrm{~mL}$ of solvent). For QY and $\tau$ calculations, refractive indexes $n$ of ethanol ${ }^{17}$ and chloroform ${ }^{18}$ and reference QY of anthracene in ethanol ${ }^{14}$ were considered.

\section{Electrochemical measurements}

Electrochemical measurements were performed on a VersaStat potentiostat using a three electrode cell involving a Pt working electrode, a Pt counter electrode and a $\mathrm{Ag} / \mathrm{AgNO}_{3}$ reference electrode ( $\mathrm{Ag}$ in $0.01 \mathrm{M} \mathrm{AgNO}_{3}$ and $0.1 \mathrm{M}$ TBAP (tetrabutyl ammonium perchlorate) acetonitrile solution). The electrolytes were deoxygenated acetonitrile solutions of complexes (6), (7) or $(8)\left(2 \times 10^{-3} \mathrm{M}\right)$, TBAP $(0.1 \mathrm{M})$ and ferrocene $\left(10^{-3} \mathrm{M}\right)$ used as an internal reference. The cyclic voltammograms were recorded during 3 cycles between $-1.75 \mathrm{~V}$ (starting potential) and $1.75 \mathrm{~V}$ vs. $\mathrm{Ag} / \mathrm{AgNO}_{3}$ at a $0.2 \mathrm{~V} \mathrm{~s}^{-1}$ scan rate.

\section{Acknowledgements}

The authors wish to thank Karine Jarsale for the mass spectroscopy spectra and Rémi Legay for NMR spectral analysis. We gratefully acknowledge financial support from the "Ministére de la Recherche et des Nouvelles Technologies", CNRS (Centre National de la Recherche Scientifique), the "Région BasseNormandie" and the European Union (FEDER funding). The authors acknowledge the financial support from the French Agence Nationale de la Recherche (ANR), through the program “Investissements d'Avenir'(ANR-10-LABX-09-01), LabEx EMC and the Vietnam National Foundation for Science and Technology Development (NAFOSTED 104.01-2012.26).

\section{Notes and references}

1 A. Loudet and K. Burgess, Chem. Rev., 2007, 107, 4891.

2 D. Frath, J. Massue, G. Ulrich and R. Ziessel, Angew. Chem., Int. Ed., 2014, 53, 2290. 
3 N. Boens, V. Leen and W. Dehaen, Chem. Soc. Rev., 2012, 41, 1130 .

4 Z. Guo, S. Park, J. Yoon and I. Shin, Chem. Soc. Rev., 2014, 43, 16.

5 G. Ulrich, R. Ziessel and A. Harriman, Angew. Chem., Int. Ed., 2008, 47, 1184.

6 A. Bessette and G. S. Hanan, Chem. Soc. Rev., 2014, 43, 3342.

7 G. Qian and Z. Y. Wang, Chem. - Asian J., 2010, 5, 1006.

8 (a) Y. Hong, J. W. Y. Lam and B. Z. Tang, Chem. Commun., 2009, 4332; (b) Y. Hong, J. W. Y. Lam and B. Z. Tang, Chem. Soc. Rev., 2011, 40, 5361; (c) X. Liu, Y. Ren, H. Xia, H. Fan and Y. Mu, Inorg. Chim. Acta, 2010, 363, 1441; (d) F. P. Macedo, C. Gwengo, S. V. Lindeman, M. D. Smith and J. R. Gardinier, Eur. J. Inorg. Chem., 2008, 3200; (e) K. Perumal, J. A. Garg, O. Blacque, R. Saiganesh, S. Kabilan, K. K. Balasubramanian and K. Venkatesan, Chem. - Asian J., 2012, 7, 2670; ( $f$ ) Y. Ren, X. Liu, W. Gao, H. Xia, L. Ye and Y. Mu, Eur. J. Inorg. Chem., 2007, 1808; (g) D. Zhao, G. Li, D. Wu, X. Qin, P. Neuhaus, Y. Cheng, S. Yang, Z. Lu, X. Pu, C. Long and J. You, Angew. Chem., Int. Ed., 2013, 52, 13676.

9 (a) J. F. Araneda, W. E. Piers, B. Heyne, M. Parvez and R. McDonald, Angew. Chem., Int. Ed., 2011, 50, 12214; (b) A. Esparza-Ruiz, A. Peña-Hueso, H. Nöth, A. Flores-Parra and R. Contreras, J. Organomet. Chem., 2009, 694, 3814; (c) D. Frath, A. Poirel, G. Ulrich, A. De Nicola and R. Ziessel, Chem. Commun., 2013, 49, 4908; (d) B. J. Liddle, R. M. Silva, T. J. Morin, F. P. Macedo, R. Shukla, S. V. Lindeman and J. R. Gardinier, J. Org. Chem., 2007, 72, 5637; (e) T. J. Morin, S. V. Lindeman and J. R. Gardinier, Eur. J. Inorg. Chem., 2009, 104; $(f)$ G. Nawn, S. R. Oakley, M. B. Majewski, R. McDonald, B. O. Patrick and R. G. Hicks, Chem. Sci., 2013, 4, 612; (g) Y. Yang, X. Su, C. N. Carroll and I. Aprahamian, Chem. Sci., 2012, 3, 610.
10 (a) G. M. Fischer, E. Daltrozzo and A. Zumbusch, Angew. Chem., Int. Ed., 2011, 50, 1406; (b) G. M. Fischer, A. P. Ehlers, A. Zumbusch and E. Daltrozzo, Angew. Chem., Int. Ed., 2007, 46, 3750; (c) G. M. Fischer, M. Isomäki-Krondahl, I. GöttkerSchnetmann, E. Daltrozzo and A. Zumbusch, Chem. - Eur. J., 2009, 15, 4857; (d) Y. Kubota, T. Tsuzuki, K. Funabiki, M. Ebihara and M. Matsui, Org. Lett., 2010, 12, 4010; (e) Q. D. Liu, M. S. Mudadu, R. Thummel, Y. Tao and S. Wang, Adv. Funct. Mater., 2005, 15, 143; $(f)$ L. Quan, Y. Chen, X.-J. Lu and W.-F. Fu, Chem. - Eur. J., 2012, 18, 14599; (g) S. Shimizu, T. Iino, Y. Araki and N. Kobayashi, Chem. Commun., 2013, 49, 1621; (h) D. Wang, R. Liu, C. Chen, S. Wang, J. Chang, C. Wu, H. Zhu and E. R. Waclawik, Dyes Pigm., 2013, 99, 240; (i) S. Wiktorowski, G. M. Fischer, M. J. Winterhalder, E. Daltrozzo and A. Zumbusch, Phys. Chem. Chem. Phys., 2012, 14, 2921; (j) Y. Zhou, Y. Xiao, D. Li, M. Fu and X. Qian, J. Org. Chem., 2008, 73, 1571.

11 F. Medda, E. Sells, H.-H. Chang, J. Dietrich, S. Chappeta, B. Smith, V. Gokhale, E. J. Meuillet and C. Hulme, Bioorg. Med. Chem. Lett., 2013, 23, 528.

12 A. T. R. Williams, S. A. Winfield and J. N. Miller, Analyst, 1983, 108, 1067-1071.

13 S. Fery-Forgues and D. Lavabre, J. Chem. Educ., 1999, 76, 1260.

14 W. R. Dawson and M. W. Windsor, J. Phys. Chem., 1968, 72, 3251-3260.

15 S. J. Strickler and R. A. Berg, J. Chem. Phys., 1962, 37, 814-822.

16 R. A. Lampert, L. A. Chewter, D. Phillips, D. V. O'Connor, A. J. Roberts and S. R. Meech, Anal. Chem., 1983, 55, 68-73. 17 S. Kedenburg, M. Vieweg, T. Gissibl and H. Giessen, Opt. Mater. Express, 2012, 2, 1588-1611.

18 A. Samoc, J. Appl. Phys., 2003, 94, 6167-6174. 